Article Type: Research Paper

\title{
Do Resource-Rich Provinces Perform Lower Democratization Progress? Estimating Oil Impact on Democracy Indicators in Indonesia
}

\section{Rian Hilmawan}

\section{APEES}

\section{AFFILIATION:}

Department of Economics, Faculty of Economics and Business, Universitas Mulawarman, East Kalimantan, Indonesia

\section{*CORRESPONDENCE:}

rian.hilmawan@feb.unmul.ac.id

THIS ARTICLE IS AVALILABLE IN:

http://journal.umy.ac.id/index.php/esp

DOI: 10.18196/jesp.v22i2.9522

\section{CITATION:}

Hilmawan, R. (2021). Do ResourceRich Provinces Perform Lower Democratization Progress? Estimating Oil Impact on Democracy Indicators in Indonesia. Jurnal Ekonomi \& Studi Pembangunan, 22(2), 256-271.

\section{ARTICLE HISTORY}

\section{Received:}

07 Aug 2020

Revised:

26 Aug 2020

$02 \mathrm{Jul} 2021$

Accepted:

11 Sep 2021

\begin{abstract}
This study examined whether oil dependence affected democracy quality by referring to provincial-level data in Indonesia. While physical quantity production was used to measure oil dependence, democracy was measured based on the Indonesian Democracy Index (IDI). Static panel data analysis was employed to control unobserved time-invariant characteristics of each province, including a robust Driscoll and Kraay (D-K) standard error model for the general forms of crosssectional dependence when dealing with panel observation. The results showed that oil-dependent provinces tended not to have weak democratic qualities. The effects were also robust when democracy was separated into three main elements of the IDI: political rights, civil liberties, and democratic institutions, or when an alternative measure of dependency was used. Interestingly, this study found that oil dependence had a stronger effect on democracy in provinces with a lack of oil than in Sumatra and Kalimantan, globally known as dominant resource locations.

Keywords: Oil; Democracy; Education; Province; Indonesia

JEL Classification: 013; D72
\end{abstract}

\section{Introduction}

Oil impact has long been understood to penetrate a country's economy substantially. Regardless of whether oil extraction activities may hinder or help the nation's welfare, attention has now moved to examine whether a country's oil dependence has a strong link with democratic progress. This issue initially emerged in countries primarily located in the Middle East and North Africa, where oil wealth was seen as a factor that stimulated authoritarianism (Anderson, 1987; Anderson, 1995). A study by Ross (2001) formally hypothesized a relationship focusing on a country's dependence on the oil sector. Ross (2001) found that oil-reliant nations, including minerals, tended to have lower quality in democracy. Therefore, this paper tested the proposed hypothesis by selecting Indonesia, a developing and young democratic country, as a special case study.

There are two reasons why Indonesia should be particularly considered. First, Indonesia's economy historically stems from oil-based income contributions. Oil production was carried out commercially in the 1970s following the successful oil reserves discovery in several Sumatra and 
Kalimantan Islands locations, which later became the forerunners of Indonesia's giant oil fields. ${ }^{1}$ The contribution of oil production to national income is still crucial to this day, although oil production experienced a gradual decrease over time. It has been proven that the oil reserves may last approximately more than 50 years as efforts to invest in deep-water explorations have been highly devoted. ${ }^{2}$

Secondly, Indonesia adhered to a democratic system across national and regional (provinces and districts) areas for almost two decades. Direct presidential election initially started in 2004 and was rapidly echoed by the direct election of regional heads in local government in 2005 . These events were triggered by the decentralization policy that allowed local governments to execute development planning, budgeting, and providing public service to local citizens. Although the democratic climate seems to blossom, no data were available to monitor development progress on this aspect, making it hard to associate the effects of whether oil wealth improves the practicality of democracy in a decentralized area. Only since 2009, the Indonesian Democracy Index (IDI) has been officially released annually, enabling researchers to verify the progress of local democracy across provinces.

The available timeframe of these exogenous events allows testing the extent to which democratic progress is affected by activities associated with hydrocarbon resources. As oil resources are randomly distributed across Indonesia's provinces (each province has several districts), some regions with oil wealth have become dependent on resourcebased economic sectors. Meanwhile, regions that have less or no oil reserves will rely on sectors unrelated to non-renewable resources.

Following Ross's (2001) study and foreshadowing it to Indonesia's decentralization movement, this research examined whether oil affects democracy and oil-dependent oversight produced a devastating effect on democracy at the provincial level. As the study using within-country analysis on this field is still lacking, this paper contributes to the literature by providing empirical investigations.

Moreover, oil is often seen as a valuable resource capital that should, by default, help to improve a country's economy or achieve better development progress. The positive effect of oil on national income has been found in several cross-country studies, for example, Alexeev and Conrad (2011), Brunnschweiler (2008), Brunnschweiler and Bulte (2008), and Libman (2013). Despite the blessing consequence that natural resources can contribute, researchers have found that countries that depended highly on the mining sector, in general, were more likely to have lower development income and outcomes (Sachs \& Warner, 2001; Papyrakis \& Gerlagh, 2004).

Another striking finding of the detrimental effect of oil is that oil wealth retards a country's democracy quality. A seminal article published by Ross (2001) initially provided

\footnotetext{
${ }^{1}$ Indonesia is an archipelago country with more than 17,000 islands in total. The six major islands, however, are Java, Sumatra, Kalimantan, Sulawesi, Maluku and East Regions, and Papua.

${ }^{2}$ Annual Report of Indonesian Oil and Gas, 2018. Available from https://migas.esdm.go.id/uploads/uploads/files/laporan-tahunan/Laptah-Migas-2018---FINAL.pdf
} 
empirical evidence as to why oil is bad for democratic development. Ross (2001) utilizing country-level data, measured democracy level using a scale ranging from 0 to 10 , with the highest value indicating the most democratic country. ${ }^{3}$ Oil dependence was employed as the key variable, measured as the share of the aggregate export-value of mining-based fuels (petroleum, gas, and coal) in total GDP. Focusing on the period between 1971 and 1977, with a pooled OLS using a cross-sectional data set, Ross (2001) found that increased oil dependence, including minerals, tended to worsen democracy quality.

One might argue that cross-country investigations could be biased due to different development levels between developed and developing countries or between AfricaMiddle East versus non-Africa-Middle East countries. Ross (2001) also addressed this possibility by controlling the locational effects of countries in the Middle East and subSaharan Africa or distinguishing them according to the country size (i.e., large and small states), both using binary variables. Again, the point estimates for oil and minerals were still significantly negative, although they had been reduced when additional control variables were included.

Referring to why oil hinders democracy in an oil-rich country, Ross (2001) argued that rentier and repression effects had weakened the process towards better civil freedom and political rights. For example, a higher mineral revenues proportion causes the government to build their internal security, enabling them to reduce or block people's demands for democracy. This reason refers to the repression effect. The second case is caused by the rentier effect. In oil-wealthy states, the dominant revenues come from oil extraction rather than citizens' taxation. It provides an incentive for the country's residents to put in less effort in paying taxes. As a result, citizens' demands on the government are reduced, making the government less dependent on its citizens, weakening checks and balances processes between the two actors, yet deteriorating democracy.

Some studies that support Ross's (2001) paper are Jensen and Wanthecekon (2004), Aslaksen (2010), and Anyanwu and Erhijakpor (2014). For example, Jensen and Wanthecekon (2004) focused on 46 countries in Sub-Saharan Africa after the 1960-1995 period. The authors utilized political regime as a proxy for democracy as Ross (2001) did with some scale modifications. Using fixed-effects analysis, they found that oil and mineral exports, as a share of merchandise exports, negatively impacted democracy in Africa, even after controlling dummies for the historical colony.

Aslaksen (2010) regressed democracy on the share of oil in total GDP using pooled crosssectional OLS regression and found that oil share harmed political rights. The negative impact persisted in whether democracy infrequently regressed, whether per capita income, population, and education were included, or whether the fixed-effects and dynamic panel model were also applied. Anyanwu and Erhijakpor (2014) compared the

\footnotetext{
3 This measure was modified from Polity scores published by Marshall and Jaggers (2005). This measure reflects the dimensions of public participation in political aspects (political rights) including the openness and competitiveness of executive recruitment. The scores originally ranged from -10 to 10 , with higher scores indicating better quality of democratic institutions.
} 


\author{
Hilmawan \\ Do Resource-Rich Provinces Perform Lower Democratization Progress? ...
}

OLS and fixed-effects model and found a stable inverse relationship between oil wealth per capita, measured using the log of oil per capita and democracy. In this research, polity 2 was used to measure democracy, which reflected competitiveness and openness representing political participation.

While the adverse effects of oil on democracy have become widely accepted, several studies have uncovered a surprising contrast result against Ross (2001). Haber and Menaldo (2012), for instance, found insignificant results once country fixed-effects were controlled. Werger (2009), using fixed-effects regression between 1960 and 2004, found that the negative impact of oil production on democracy decreased once the model incorporated per capita income and population. Arezki and Bruckner (2011) disclosed that a change in oil rents raised civil liberties. Similarly, a study by Brückner (2012) exposed that an increase in the share of international oil prices raised democratic institutions. Herb (2005) also initially argued that the negative relationship between oil and democracy was simply a matter of geographic sampling as previous studies relied heavily on countries in the Middle East and North Africa.

Oskarsson and Ottosen (2010) conducted an in-depth study that criticized the democracy variable used in previous studies (e.g., Jensen \& Wanthecekon, 2004; Smith, 2004; Tsui, 2010). They argued that most studies in the past were focused on the political rights index (polity), ignoring civil liberties components, such as freedom of assembly to form organizations, and not considering freedom of the press, which can better capture democracy dimensions. The studies confirming Ross's (2001) findings are also limited by the time horizon, essential for robustness. Oskarsson and Ottosen (2010) then empirically tested the hypothesis by proposing an alternative democracy score from Freedom House $(\mathrm{FH})$, which included the civil freedom aspect to complement the traditional polity index used in the previous studies. To examine temporal stability, Oskarsson and Ottosen (2010) also employed different periods, comparing the old periods in 1977-1999 and new periods within 2000-2006, according to panel data in 132 countries. They found that the democracy quality became unaffected by oil when democracy was measured utilizing the $\mathrm{FH}$-index, with some surprising positive evidence of oil or mineral dependence (defined as the percentage of GDP), when democracy scores referred to political rights and civil liberties, respectively.

In addition, Acemoglu et al. (2005) also examined whether democracy performance was determined by per capita income, as suggested in another influential study by Barro (1999). The authors uncovered that once countries' unobserved effects were included, per capita income became insignificant, but education strongly affected democracy. This finding suggests that education should be added as an important control to detect the direct influence of oil on the countries' democracy level.

Reviewing the highlighted literature as above, it is clear that the topic between oil and its relationship with democracy is still a developing topic to be studied, and while the existing literature has shed some light, many of them were concentrated using cross-country datasets. For this reason, this study offered room to fill the gap by adopting in-country analysis. To the best of the author's knowledge, the author could not find similar studies 


\author{
Hilmawan \\ Do Resource-Rich Provinces Perform Lower Democratization Progress? ...
}

establishing a link between oil or mining dependence and democracy in Asia, nor Indonesia.

This paper is then structured as follows: Section 2 explains the author's data sources, including the variable size and the research methods used in this study. Section 3 demonstrates the results and discusses the relevant findings associated with the purpose of the paper. Section 5 presents the conclusion.

\title{
Research Method
}

Since oil export data were not available at the provincial level in Indonesia, the author used physical production (lifting) as it closely captured the cross-provincial export level in Indonesia. Data on the physical quantity of oil production (in barrels) were obtained from the Ministry of Energy and Mineral Resources (MoEMR). Oil production in a province was the amount of oil produced in all districts of the relevant province, specifically calculating oil wells operated onshore or offshore or both in the respective area. Respecting Ross's (2001) study, the researcher divided each province's oil production with the total national production to measure it as a share. Again, for robustness check, the researcher also divided the province's oil lifting by its population according to the Indonesian census data in 2010 , allowing the researcher to measure it as per capita value.

Regarding the democracy variable, the researcher employed the Indonesian Democracy Index (IDI) released in 2009 by the Indonesian Central Statistical Bureau (BPS). The IDI encompasses three fundamental aspects, namely civil freedom, political rights, and democratic institutions. These aspects were then decomposed into 11 variables and 28 indicators to obtain a single composite index of IDI. This democracy index had a scale of 0 to 100 , where a higher value meant better improvement at the level of democracy. The researcher then rescaled this from 0 to 1 to match the scale of this study's key independent variable that used the proportion value. In addition, the researcher limited the period to only 2009-2016, following the availability data of IDI. The IDI reflects dimensions similar to the well-known FH democracy indicators used by Aslaksen (2010) and Oskarsson and Ottosen (2010), which give more weight to political rights and civil liberties as the key components.

As in Ross (2001), Aslaksen (2010), and Oskarsson and Ottosen (2010), some control variables were also included. The income per capita is hypothesized to increase prosperity, thereby improving the demands of democracy. Better educated people are expected to increase political representations, enhance public awareness, and improve the quality of democracy (Acemoglu et al., 2005; Barro 1999). To measure this, the researcher used the human development index (HDI) as a proxy. The researcher was also interested in adding variables capturing the dynamics of women's contributions in each province, which were believed to affect democracy sustainability (Gberevbie \& Oviasogie, 2013). For this aim, the researcher utilized the proportion of women involved in formal and professional work. The researcher also included internet use as the important control variable. Some recent studies have emphasized internet exposure as a driving factor in 
Hilmawan
Do Resource-Rich Provinces Perform Lower Democratization Progress? ...

reinforcing democratic practices (Pirannejad, 2017; Evans, 2019) or reducing people's satisfaction towards democracy (Chang, 2017). Thus, the researcher collected information about the percentage of "households" that used the internet in the last three months. The researcher was also aware that previous studies had controlled religion to capture the proportion of people who embraced Islam. However, based on Indonesia's census in 2010, the majority of the population across provinces in Indonesia were affiliated as "Muslims", while data related to them were unavailable over time. The researcher excluded this point as the control of the study. All data used for these explanatory variables were also collected from BPS. ${ }^{4}$

The estimation strategy consisted of two parts. First, considering that the observation contained several provinces across different islands, estimation based on the fixed-effects (FE) method to control for factors caused by the unobserved heterogeneity in these provinces was preferred. The static model was then constructed as follows:

$\operatorname{DEMOC}_{i, t}=\alpha+O I L_{i, t}+\beta^{\prime} X_{i, t}+\mu_{i}+\gamma_{t}+\varepsilon_{i, t}$

Here, the researcher regressed the quality of democracy $\left(D E M O C_{i, t}\right)$ on this study's key variable, oil dependence or $O I L_{i, t}$. Democracy was measured by the IDI. The researcher also used each component of the IDI, namely civil freedom (CF), political rights (PR), and democracy institutions (DI) as mentioned above, as alternative-dependent variables, following the strategy used by Oskarsson and Ottosen (2010). OIL $L_{i, t}$ is a share of oil produced by each province in total oil production and is the share per population as in Haber and Menaldo (2011) or Aslaksen (2010). ${ }^{5}$

The constant provincial fixed effects were indicated by $\mu_{i}$, while $X_{i, t}$ was a set of vectors indicating the control variables. The subscripts $i=1,2,3, \ldots \ldots, 33$ for 33 provinces across all islands in Indonesia, and $t=1,2,3, \ldots . .8$, for the eight years, made the time series smaller than the number of the cross-sectional identifier. Given this fact, a more advanced static panel model, such as a feasible general least square (FGLS), was not suitable (Reed $\&$ Ye, 2009). A short period also provided a restriction to effectively perform lagged independent variables technique or use a more advanced dynamic panel model.

The estimation that relied on panel data might suffer from a cross-sectional dependency problem, resulting in biased estimation. Therefore, the researcher complemented the fixed effects model by performing the Driscoll and Kraay (D-K) (1998) standard errors as it suited the specification of the data set when $i>t$. The D-K method, as emphasized in Hoechle (2007), was robust in the case of heteroscedasticity, autocorrelated with MA( $q)$, and the appearance of a cross-sectional dependent. ${ }^{6}$ Thus, the researcher followed this

\footnotetext{
${ }^{4}$ The year for HDI and woman participation starts from 2010 onwards.

${ }^{5}$ As summarised in descriptive statistics (see Table 5), the oil dependence measurement contains 0 values. This prevents the researcher to transform it into a logarithmic form. Also, as it used the share or proportions rather than level, it was infrequent to convert it as logs (see Wooldrige, 2016, p.194-195, for detailed explanations).

${ }^{6}$ The PCSE (Panel Corrected Standard Errors) method is also a good alternative and can be done in Stata using xtpcse command, but again since the number of observations the researcher used was greater than $\mathrm{T}$, the researcher prefered D-K method (Hoecle, 2007).
} 
procedure in all estimations. The Pesaran $C D$ test was also used for the first time to detect the presence or absence of cross-sectional dependence (De Hoyos \& Sarafidis, 2006).

Finally, the researcher also tested whether oil lowered democracy performance in provinces with higher oil dependence than less or no oil. To do so, the samples were separated into two categories. Provinces less dependent on oil were grouped in Java and other regions, while oil-rich provinces were grouped in Sumatra and Kalimantan. The analysis was then repeated as in Eq. (1) to check whether different results appeared.

\section{Result and Discussion}

\section{Descriptive Analysis}

The researcher began by showing descriptive figures regarding the key variables used, while the average comparison was also shown right after. The descriptive statistics are shown in Table 5. Figure 1 presents scatterplots between the average share of oil production and the aggregate index of democracy quality (IDI) over 2009-2016, including the three core aspects of IDI. For clarity, the approximate lines in each graph were also shown. As shown, there was a positive correlation between oil dependence and IDI, and each index related to political rights and democratic institutions in 33 provinces was observed. The researcher also found a slight negative pattern on the civil freedom index, although the predicted linear line was insignificant.
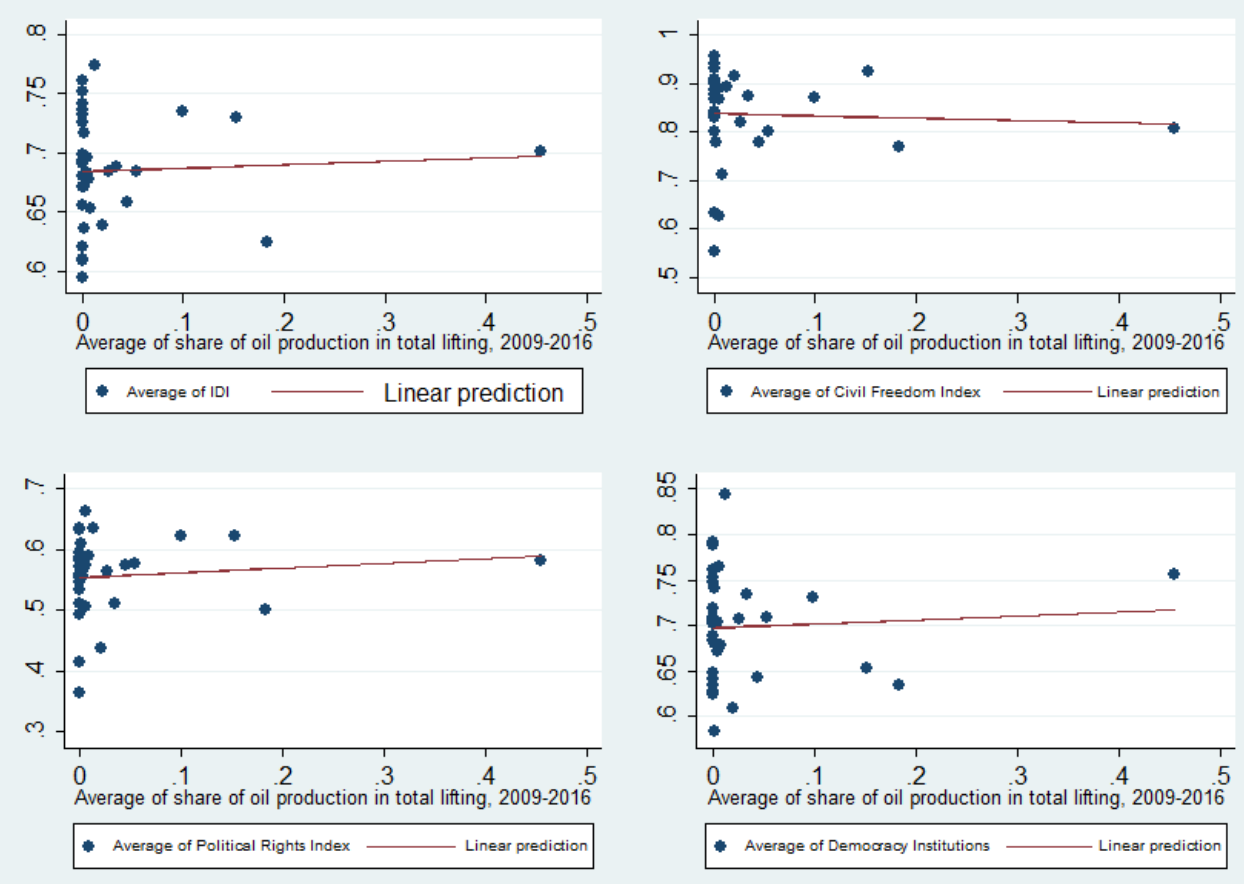

Figure 1 Relationship between the share of oil production and IDI (2009-2016) 
Figure 2 compares average oil production between 2009 and 2016, grouped into the seven largest islands in Indonesia (Sumatra, Java, Kalimantan, Maluku and the East Regions, Sulawesi, and Papua). As predicted, Sumatra became the highest contributor, with production stood at 18.4 million barrels. Kalimantan and Java followed with 9.5 million barrels on average. The remainder regions showed production levels below five million barrels, with Papua as the highest producer among other regions.

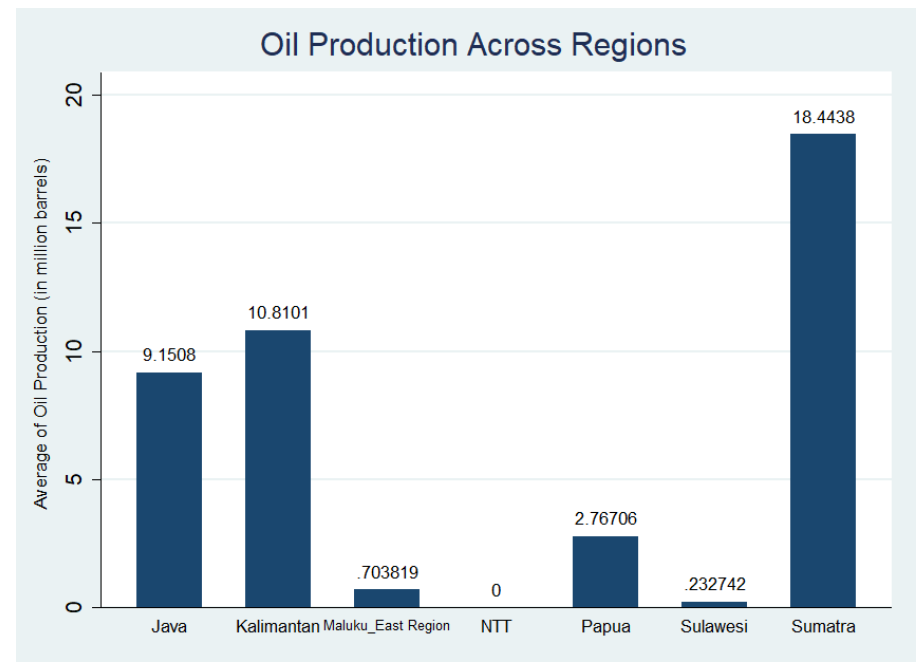

Figure 2 Comparison of oil production across Indonesia's major islands

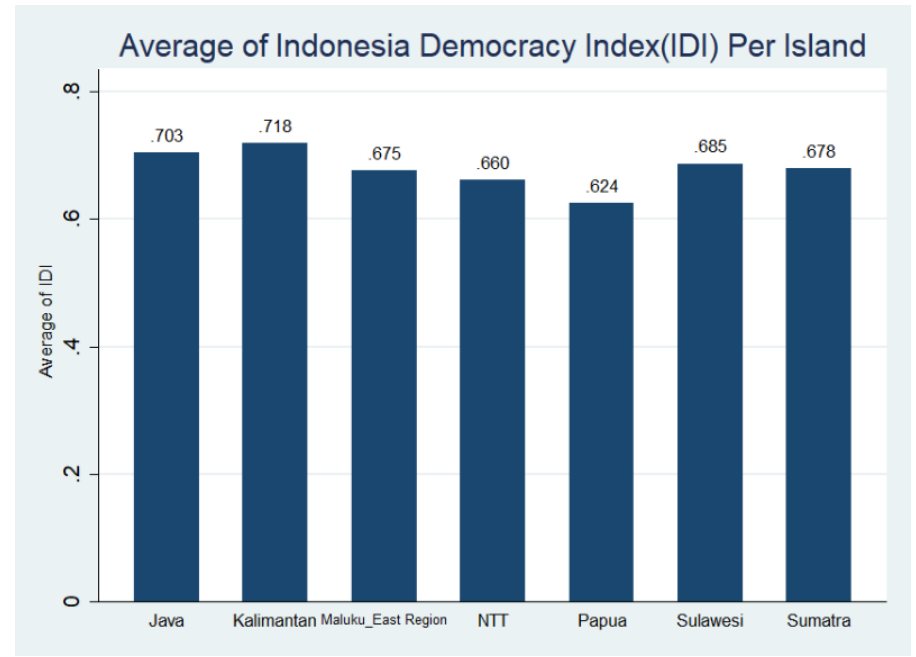

Figure 3 Comparison of democracy level across Indonesia's major islands

As shown in Figure 3, comparatively, Sumatra, which produced the highest oil output, did not automatically achieve a higher democracy index, while Kalimantan and Java had good performance compared to the rest. Interestingly, the oil-poor island of Sulawesi ranked fourth place with a better IDI than Sumatra as the oil-rich region. The graph also shows that Papua had the lowest democracy index during the observed period. To obtain strong 
Hilmawan
Do Resource-Rich Provinces Perform Lower Democratization Progress? ...

evidence for these revealed descriptive patterns, a regression analysis was conducted to formally examine the impact of oil dependence on local democracy indicators in Indonesia.

\section{The Effects of Oil on Democracy}

Moving on to results, Table 2 presents the effect of oil production's share on the aggregated index of democracy (IDI). All models controlled the provincial fixed effects and performed Driscoll Kraay (D-K) standard errors as Pesaran CD tests significantly rejected the null hypothesis of no cross-sectional dependence.

In columns (1) - (4), Table 1, it was interestingly found that local democracy was positively affected by the share of oil production, where all coefficients were statistically significant at a 1 percent level. The point estimates were large in columns (3) and (4) when more determinants of democracy were included. Referring to column (4), for example, an increase of one percentage point in the share of oil in total production increased IDI by $0.005(=0.462 * 0.01)$. If the average value of the IDI were 0.685 , then the IDI would be 0.690 , and a relative change would increase to $(0.690-0.685 / 0.685=) 0.71$ percent. Alternatively, by standardizing the coefficient, increasing the share of oil production in the total production by one standard deviation would increase IDI by $\left([0.088 / 0.066]^{*} 0.462=\right) 0.607$ standard deviations, holding all others constant. ${ }^{7}$

The researcher also found that households' use of the internet and the share of women's participation in professional jobs were positively correlated with democracy level, although the magnitudes were small, and the effect of gender was no longer significant, as shown in columns (3) - (4). Gini ratio in urban districts also showed negative signs across all models as expected but insignificant. As for per capita income, the researcher uncovered a positive sign but again not significant in most of the models used. Education, in particular, has proven to be a strong determinant of the democracy level in Indonesia, where the estimated coefficient was above 1 . For example, HDI raised IDI by $(1.460 * 0.01=) 0.015$ points when HDI increased by one percentage point.

For robustness, the researcher used an alternative measure of oil abundance based on its per capita value. All results are depicted in Table 2. Controlling other variables in the previous model, the results remained consistent with the positive coefficients found for oil per capita, although only significant in columns (3) and (4) but at a 1 percent level. In particular, taking column (4) as an example to compare with the result in Table 1, the democracy index only improved by $(0.642 * 0.01=) 0.006$ points when oil per capita rose by one percentage point. It suggests that even both measures of oil dependence showed a positive effect, it was found that the share of oil production had a strong implication on the democracy index in the province. Regarding other determinants, it was found that a

\footnotetext{
7 Standardized coefficients or Beta coefficients measure the standard deviation change in a dependent variable caused by a standard deviation increase in an independent variable (Wooldridge, 2016:768). The calculation for the Beta coefficient is obtained by multiplying the $\hat{\beta}_{1}$ with the ratio of standard deviation of $x_{1}$ to the standard deviation of the dependent variable (see Wooldridge, 2016, p.169).
} 


\section{Hilmawan}

Do Resource-Rich Provinces Perform Lower Democratization Progress? ...

similar effect of internet use was positively correlated with democracy, as predicted in the literature, whereas HDI remained to increase democracy.

Table 1 The effects of oil production on democracy quality

\begin{tabular}{|c|c|c|c|c|}
\hline \multicolumn{5}{|l|}{ Dependent Variable: IDI } \\
\hline & (1) & (2) & (3) & (4) \\
\hline \multirow[t]{2}{*}{ Share of Oil Production } & $0.365^{* * *}$ & $0.444 * * *$ & $0.513^{* * *}$ & $0.462 * * *$ \\
\hline & $(0.047)$ & $(0.064)$ & $(0.069)$ & $(0.075)$ \\
\hline \multirow{2}{*}{ Income per capita (in logs) } & 0.037 & $0.034^{*}$ & 0.009 & -0.002 \\
\hline & $(0.020)$ & $(0.015)$ & (0.014) & $(0.012)$ \\
\hline \multirow[t]{2}{*}{ Gini Ratio } & & -0.009 & -0.175 & -0.229 \\
\hline & & $(0.157)$ & (0.153) & (0.155) \\
\hline \multirow[t]{2}{*}{ Woman Participation } & & $0.006 * * *$ & 0.001 & 0.000 \\
\hline & & $(0.001)$ & $(0.001)$ & $(0.001)$ \\
\hline \multirow[t]{2}{*}{ Internet Use } & & & $0.003 * * *$ & $0.001 * *$ \\
\hline & & & $(0.001)$ & $(0.000)$ \\
\hline \multirow[t]{2}{*}{ HDI } & & & & $1.460 * * *$ \\
\hline & & & & $(0.340)$ \\
\hline \multirow[t]{2}{*}{ Constant } & $0.595 * * *$ & $0.330 * *$ & $0.595 * * *$ & -0.267 \\
\hline & $(0.030)$ & $(0.089)$ & $(0.065)$ & $(0.249)$ \\
\hline Fixed Effects & YES & YES & YES & YES \\
\hline D-K Standard Errors & YES & YES & YES & YES \\
\hline R-squared & 0.055 & 0.112 & 0.289 & 0.320 \\
\hline Observations & 264 & 231 & 231 & 231 \\
\hline Number of groups & 33 & 33 & 33 & 33 \\
\hline
\end{tabular}

Note: ${ }^{*}, * *$, and ${ }^{* * *}$ imply statistical significance at the 10,5 , and 1 percent levels, respectively.

Table 2 The effects of oil per capita on democracy

\begin{tabular}{lllll}
\hline Dependent Variable: IDI & $(1)$ & $(2)$ & $(3)$ & $(4)$ \\
\hline Oil Per Capita & 0.042 & 0.026 & $0.743^{* * *}$ & $0.642^{* * *}$ \\
& $(0.191)$ & $(0.112)$ & $(0.141)$ & $(0.151)$ \\
Income per capita (in logs) & 0.004 & $0.004^{*}$ & 0.001 & -0.000 \\
\hline Gini Ratio & $(0.002)$ & $(0.002)$ & $(0.001)$ & $(0.001)$ \\
& & 0.003 & -0.012 & -0.018 \\
Woman Participation & & $(0.016)$ & $(0.016)$ & $(0.016)$ \\
& & $0.001^{* * *}$ & 0.000 & -0.000 \\
Internet Use & & $(0.000)$ & $(0.000)$ & $(0.000)$ \\
& & & $0.0003^{* * *}$ & $0.0001^{* *}$ \\
HDI & & & $(0.000)$ & $(0.000)$ \\
& & & & $0.151^{* * *}$ \\
Constant & $0.060^{* * *}$ & $0.034^{* *}$ & $0.057^{* * *}$ & $(0.033)$ \\
& $(0.003)$ & $(0.010)$ & $(0.007)$ & -0.031 \\
Fixed Effects & YES & YES & YES & YES \\
\hline D-K Standard Errors & YES & YES & YES & YES \\
R-Squared & 0.035 & 0.085 & 0.272 & 0.305 \\
Observations & 264 & 231 & 231 & 231 \\
Number of groups & 33 & 33 & 33 & 33 \\
\hline
\end{tabular}

Note: ${ }^{*}, * *$ and ${ }^{* * *}$ imply statistical significance at the 10,5 , and 1 percent levels, respectively. 
Moving on to Table 3, the models in Table 1 and Table 2 are replicated and divided into two groups: Java \& others ${ }^{8}$ and Sumatra \& Kalimantan. The emphasis here is for Sumatra and Kalimantan as these islands are known as oil-rich areas. It was rediscovered that despite sample separation was conducted, oil dependence was still positively correlated with democracy level. Interestingly, the estimated coefficients of oil production share in the provinces in the first group were larger than those in Sumatra and Kalimantan.

Table 3 The effects of oil on each aspect of democracy

\begin{tabular}{|c|c|c|c|c|}
\hline \multicolumn{5}{|l|}{ Dependent Variable: IDI } \\
\hline & (1) & $(2)$ & (3) & (4) \\
\hline & $\begin{array}{l}\text { Java \& other } \\
\text { regions }\end{array}$ & $\begin{array}{l}\text { Java \& other } \\
\text { regions }\end{array}$ & $\begin{array}{l}\text { Sumatra \& } \\
\text { Kalimantan }\end{array}$ & $\begin{array}{l}\text { Sumatra \& } \\
\text { Kalimantan }\end{array}$ \\
\hline \multirow[t]{2}{*}{ Share of Oil Production } & $0.426 * * *$ & & $0.145^{*}$ & \\
\hline & $(0.087)$ & & $(0.072)$ & \\
\hline \multirow[t]{2}{*}{ Oil Per Capita } & & $6.016 * * *$ & & $0.325 * *$ \\
\hline & & $(0.950)$ & & $(0.097)$ \\
\hline \multirow[t]{2}{*}{ Income per capita (in logs) } & 0.009 & 0.001 & -0.004 & -0.000 \\
\hline & $(0.012)$ & $(0.001)$ & $(0.026)$ & $(0.003)$ \\
\hline \multirow[t]{2}{*}{ Gini Ratio } & -0.017 & 0.005 & $-0.494 * *$ & $-0.047 * *$ \\
\hline & $(0.174)$ & $(0.016)$ & $(0.194)$ & (0.019) \\
\hline \multirow[t]{2}{*}{ Woman Participation } & 0.000 & -0.000 & -0.000 & 0.000 \\
\hline & $(0.000)$ & $(0.000)$ & $(0.002)$ & $(0.000)$ \\
\hline \multirow[t]{2}{*}{ Internet Use } & 0.001 & 0.000 & $0.001^{* *}$ & $0.0001 * * *$ \\
\hline & $(0.000)$ & $(0.000)$ & $(0.000)$ & $(0.000)$ \\
\hline \multirow[t]{2}{*}{ HDI } & $2.048 * * *$ & $0.202 * * *$ & 0.736 & 0.063 \\
\hline & $(0.360)$ & $(0.043)$ & $(0.460)$ & $(0.043)$ \\
\hline \multirow[t]{2}{*}{ Constant } & $-0.728 * *$ & $-0.076 * *$ & 0.322 & 0.037 \\
\hline & $(0.243)$ & $(0.027)$ & $(0.328)$ & $(0.031)$ \\
\hline Fixed Effects & YES & YES & YES & YES \\
\hline D-K Standard Errors & YES & YES & YES & YES \\
\hline R-Squared & 0.422 & 0.437 & 0.242 & 0.246 \\
\hline Observations & 133 & 133 & 97 & 97 \\
\hline Number of groups & 19 & 19 & 14 & 14 \\
\hline
\end{tabular}

The same finding was also found for oil per capita. In particular, for example, holding all other factors constant, democracy increased by $\left(0.426^{*} 0.01=\right) 0.004$ points when the share of oil production in Java provinces increased by one percentage point, significant at a 1 percent level. Meanwhile, it only raised the democracy quality by $(0.145 * 0.01=) 0.001$ points in provinces located in Sumatra and Kalimantan, with statistically significant only at the 10 percent level. The point estimates differed substantially between these two groups. For example, a difference of 0.281 for oil production and 5.691 for oil per capita was found. These findings suggested that although oil dependence had helped increase the overall democracy level, oil impact in oil-deficient provinces or provinces with lack or no oil endowments achieved better democracy quality than provinces with dominant oil resources.

${ }^{8}$ I combine provinces in Java, Maluku and East Regions, NTT, Papua, and Sulawesi in this group. 
Hilmawan
Do Resource-Rich Provinces Perform Lower Democratization Progress? ...

\section{Oil Effects on Particular Aspects of Democracy}

Finally, if oil dependence generally helps Indonesia's democratic environment, does it also affect Indonesia's particular aspect of democracy? Table 4 presents the results regarding this question by comparing civil freedom, political rights, and democratic institutions, where each was placed as the dependent variable, and the researcher regressed them separately on the oil measures as before. To save space, attention is now focused on estimation associated with the key independent variables.

Table 4 Effects of oil on each aspect of democracy

\begin{tabular}{lcccccc}
\hline Variables & $(1)$ & $(2)$ & $(3)$ & $(4)$ & $(5)$ & $(6)$ \\
\hline Oil Production & CF & PR & DI & CF & PR & DI \\
\hline Oil Per Capita & $0.051^{* * *}$ & $0.030^{*}$ & $0.066^{* *}$ & & & \\
& $(0.007)$ & $(0.013)$ & $(0.026)$ & & & \\
Constant & & & & $1.733^{* * *}$ & -0.267 & 0.727 \\
& & & & $(0.271)$ & $(0.382)$ & $(0.375)$ \\
& $0.204^{* * *}$ & - & -0.005 & $0.204^{* * *}$ & - & -0.012 \\
Controls & & $0.224^{* * *}$ & & & $0.231^{* * *}$ & \\
Fixed Effects & $(0.026)$ & $(0.040)$ & $(0.045)$ & $(0.017)$ & $(0.042)$ & $(0.044)$ \\
D-K Standard Errors & YES & YES & YES & YES & YES & YES \\
R-Squared & YES & YES & YES & YES & YES & YES \\
Observations & YES & YES & YES & YES & YES & YES \\
Number of groups & 0.078 & 0.058 & 0.098 & 0.113 & 0.589 & 0.083 \\
\hline
\end{tabular}

Note: Civil Freedom (CF), Political Rights (PR) and Democracy Institutions (DI). ${ }^{*},{ }^{* *}$ and *** imply statistical significance at the 10,5 , and 1 percent levels, respectively.

As shown, the researcher also exposed consistent results across all specifications within a particular dimension in democracy. As measured by its share in total production, oil was positively correlated with each dimension, with the indicator in democratic institutions being particularly affected. However, different results appeared when oil was measured based on a per capita basis. There was no evidence that oil had improved political rights and democratic institutions, except for civil freedom. For example, in column (4), increasing the value of oil per capita by one percentage point raised the civil freedom value by 0.017 points. However, in column (1), using the share of oil production, civil freedom only increased by 0.001 points, ceteris paribus.

The finding of this study contradicts Ross's study, which showed that oil dependence positively affected democracy. As democracy measure(s) used reflected indicators according to FH dimensions, a positive effect was found on democracy, particularly civil liberties. These results align with Arezki and Bruckner's (2011) and specifically Oskarsson and Ottosen's (2010) studies, emphasizing the FH scores. The researcher followed arguments built by Oskarsson and Ottosen (2010), which suggested that the negative relationship between oil and democracy found in the previous studies might be caused by inadequate measurements to calculate democracy aspects better. For example, once indicators capturing civil liberties are better weighted, the oil effect no longer exists or fosters democracy. Oskarsson and Ottosen (2010) also highlighted the issues connected 


\author{
Hilmawan \\ Do Resource-Rich Provinces Perform Lower Democratization Progress? ...
}

to temporal variations, resulting in different consequences once the new periods were added.

Another justification of why the findings in this research differed might be due to the different scopes observed. Previous studies have repeatedly used cross-country explorations, which might not fully control the effects of countries' heterogeneity. In contrast, the within-country approach in this study removed country heterogeneity issues while regional differences across provinces could still be controlled by incorporating the fixed effects method.

Interesting results were also found, where oil impacts in provinces clustered in Java and other regions showed better democratic performance than provinces with a high oil track record. As provinces in Java generally have better institutional capacity and infrastructure factors, this may exogenously contribute to strengthening local democracy in these areas. Furthermore, two factors might contribute to oil production, thereby strengthening Indonesia's democracy. First, as oil generates revenues to provinces and districts, local governments may respond in the form of better spending decisions, which could strengthen particular aspects of democracy, such as democratic institutions and civil awareness. Oil also generates income, which promotes democracy through the expansions of the middle class in society (Leonard, 2019). The researcher also uncovered that in all the regression models used, education had been a positive contributor to the democracy level in Indonesia.

Second, the researcher argued that testing the effects driven by oil wealth on the "quality" of democracy should be more relevant in a country that has just transformed to practice democratization values. For example, country $A$ and country $B$ both depend on oil as a state income source, but country $A$ is recently shifted to adopt a democratic system, say a decade ago, while country $B$ remains under their authoritarian political regime. The windfalls from oil across regions in country A will be more varied since, in a young democratic country, people tend to use this environment to express their political aspirations yet raising freedom. In contrast, for country $B$, as the political regime partly or entirely blocks public participation, the magnitude of the oil windfalls seems to create a small or detrimental effect, which suggests that it is unlikely to improve democracy.

\title{
Conclusion
}

This study assessed the links between oil abundance and democracy using Indonesia as a sample of developing countries in Asia. This study contributes to the lack in the number of studies addressing this issue specifically to within-country. In this research, the provincial fixed effects were used along with Driscoll-Kraay's robust standard errors to deal with arbitrary forms of heteroscedasticity, serial correlation, and cross-section dependence in the panel data model. This study also utilized two oil dependence measurements, based on production and per capita value, and tested the locational effects by dividing the sample. This study also scrutinized whether oil was also mattered in particular aspects of Indonesian democracy. 
The main finding did not confirm the hypothesis, which elaborated that oil rents weaken democracy performance. On the other hand, it was found that oil dependence did improve Indonesia's democracy quality, whether measured based on its aggregate index value or when democracy was divided based on the index of specific democracy aspects. Another finding is that oil was strongly associated with civil liberties in particular, rather than with political rights and democratic institutions. Finally, this study uncovered that oil's impact on democracy quality in Java and other regions lacking oil resources was stronger than in resource-rich provinces, such as Sumatra and Kalimantan. It might suggest that institutional capabilities mattered as it was widely understood that the provinces in Java owned better-established government and bureaucracy systems than other provinces.

However, this study was limited as it was only conducted at the provincial level, given that data on the democracy quality were not available at the district level. This study also did not provide wide time intervals due to the availability of data, making it only a short observation duration could be analyzed, and this suggested that tests of temporal stability had not been sufficiently investigated. Therefore, subsequent research, which emphasizes within-country situations as previously described, is worth pursuing.

\section{Appendix}

Table 5 Descriptive statistics

\begin{tabular}{lccccc}
\hline \multicolumn{1}{c}{ Variable } & Obs & Mean & Std. Dev. & Min & Max \\
\hline IDI & 264 & 0.685353 & 0.066787 & 0.5261 & 0.8558 \\
Civil Freedom & 264 & 0.08367 & 0.011645 & 0.04721 & 0.1 \\
Political Rights & 264 & 0.055643 & 0.012406 & 0.02895 & 0.08577 \\
Democracy Institution & 264 & 0.069916 & 0.010159 & 0.0447 & 0.0935 \\
Share of Oil Production & 264 & 0.033667 & 0.088067 & 0 & 0.503516 \\
Oil Per Capita & 264 & 0.001891 & 0.00464 & 0 & 0.027594 \\
Income per capita (in logs) & 264 & 2.10745 & 0.758225 & 0.302138 & 4.747099 \\
Gini Ratio & 264 & 0.372144 & 0.044756 & 0.259 & 0.475 \\
Share of Woman Participation & 231 & 47.05931 & 5.326302 & 31.56 & 59.55 \\
Internet Use (\%) & 264 & 28.87511 & 14.39659 & 4.15 & 76.96 \\
HDI & 231 & 0.673888 & 0.043982 & 0.5445 & 0.796 \\
\hline
\end{tabular}

\section{References}

Acemoglu, D., Johnson, S., Robinson, J. A., \& Yared, P. (2005). From education to democracy? American Economic Review, 95(2), 44-49. https://doi.org/10.1257/000282805774669916

Alexeev, M., \& Conrad, R. (2011). The natural resource curse and economic transition. Economic Systems, 35(4), 445-461. https://doi.org/10.1016/j.ecosys.2010.10.003

Anderson, L. (1987). The state in the Middle East and North Africa. Comparative Politics, 20(1), 1-18. https://doi.org/10.2307/421917

Anderson, L. (1995). Peace and democracy in the Middle East: the constraints of soft budgets. Journal of International Affairs, 49(1), 25-44. Retrieved from http://www.jstor.org/stable/24357441 
Anyanwu, J. C., \& Erhijakpor, A. E. O. (2014). Does oil wealth affect democracy in Africa? African Development Review, 26(1), 15-37. https://doi.org/10.1111/1467-8268.12061

Arezki, R., \& Brückner, M. (2011). Oil rents, corruption, and state stability: Evidence from panel data regressions. European Economic Review, 55(7), 955-963. https://doi.org/10.1016/j.euroecorev.2011.03.004

Aslaksen, S. (2010). Oil and democracy: More than a cross-country correlation? Journal of Peace Research, 47(4), 421-431. https://doi.org/10.1177/0022343310368348

Barro, R. J. (1999). Determinants of democracy. Journal of Political Economy, 107(S6), S158S183. https:// doi.org/10.1086/250107

Brückner, M., Ciccone, A., \& Tesei, A. (2012). Oil price shocks, income, and democracy. The Review of Economics and Statistics, 94(2), 389-399. Retrieved from http://www.jstor.org/stable/23262078

Brunnschweiler, C. N. (2008). Cursing the blessings? natural resource abundance, institutions, and economic growth. World Development, 36(3), 399-419. https://doi.org/10.1016/i.worlddev.2007.03.004

Brunnschweiler, C. N., \& Bulte, E. H. (2008). The resource curse revisited and revised: A tale of paradoxes and red herrings. Journal of Environmental Economics and Management, 55(3), 248-264. https://doi.org/10.1016/i.jeem.2007.08.004

Chang, W.-C. (2017). Media use and satisfaction with democracy: testing the role of political interest. Social Indicators Research, 140(3), 999-1016. https://doi.org/10.1007/s11205$\underline{017-1806-y}$

De Hoyos, R. E., \& Sarafidis, V. (2006). Testing for cross-sectional dependence in panel-data models. The Stata Journal, 6(4), 482-496. https://doi.org/10.1177/1536867X0600600403

Driscoll, J. C., \& Kraay, A. C. (1998). Consistent covariance matrix estimation with spatially dependent panel data. Review of Economics and Statistics 80, 549-560.

Evans, O. (2019). Digital politics: internet and democracy in Africa. Journal of Economic Studies, 46(1), 169-191. https://doi.org/10.1108/jes-08-2017-0234

Gberevbie, D. E., \& Oviasogie, F. O. (2013). Women in governance and sustainable democracy in Nigeria, 1999-2012. Economics \& Sociology, 6(1), 89-107. https://doi.org/10.14254/2071-789x.2013/6-1/8

Haber, S., \& Menaldo, V. (2011). Do natural resources fuel authoritarianism? a reappraisal of the resource curse. American Political Science Review, 105(1), 1-26. https://doi.org/10.1017/s0003055410000584

Haber, S., \& Menaldo, V. (2012). Natural resources and democracy in Latin America. Oxford Handbooks Online.

Herb, M. (2005). No representation without taxation? rents, development, and democracy. Comparative Politics, 37(3), 297-316. https://doi.org/10.2307/20072891

Hoechle, D. (2007). Robust standard errors for panel regressions with cross-sectional dependence. The Stata Journal, 7(3), 281-312. https://doi.org/10.1177/1536867X0700700301

Jensen, N., \& Wantchekon, L. (2004). Resource wealth and political regimes in Africa. Comparative Political Studies, 37(7), 816-841. https://doi.org/10.1177/0010414004266867

Leonard, L. (2019). Oil, democracy, and development in Africa. African Studies Review, 62(1), E4-E6. https://doi.org/10.1017/asr.2018.94

Libman, A. (2013). Natural resources and sub-national economic performance: Does subnational democracy matter? Energy Economics, 37, 82-99.

https://doi.org/10.1016/j.eneco.2013.02.003 


\section{Hilmawan}

Do Resource-Rich Provinces Perform Lower Democratization Progress? ...

Oskarsson, S., \& Ottosen, E. (2010). Does oil still hinder democracy? Journal of Development Studies, 46(6), 1067-1083. https://doi.org/10.1080/00220380903151058

Papyrakis, E., \& Gerlagh, R. (2004). The resource curse hypothesis and its transmission channels. Journal of Comparative Economics, 32(1), 181-193. https://doi.org/10.1016/j.jce.2003.11.002

Pirannejad, A. (2017). Can the internet promote democracy? A cross-country study based on dynamic panel data models. Information Technology for Development, 23(2), 281-295. https://doi.org/10.1080/02681102.2017.1289889

Reed, W. R., \& Ye, H. (2009). Which panel data estimator should I use? Applied Economics, 43(8), 985-1000. https://doi.org/10.1080/00036840802600087

Ross, M. L. (2001). Does oil hinder democracy? World Politics, 53(3), 325-361. https://doi.org/10.1353/wp.2001.0011

Sachs, J. D., \& Warner, A. M. (2001). The curse of natural resources. European Economic Review, 45(4-6), 827-838. https://doi.org/10.1016/S0014-2921(01)00125-8

Smith, B. (2004). Oil wealth and regime survival in the developing world, 1960-1999. American Journal of Political Science, 48(2), 232-246. https://doi.org/10.1111/j.00925853.2004.00067.x

Tsui, K. K. (2011). More oil, less democracy: Evidence from worldwide crude oil discoveries. The Economic Journal, 121(551), 89-115. Retrieved from https://voxeu.org/article/arabuprising-more-oil-less-democracy?quicktabs tabbed recent articles block $=0$

Werger, C. (2009). The effect of oil and diamonds on democracy: $i$ there really a resource curse? In OxCarre Research Papers.

Wooldridge, J. (2016). Introductory Econometrics. (6 $6^{\text {th }}$ Edition). Cengage Learning. 